\title{
Pemanfaatan Zat Warna Alam Kayu Jambal (Pelthophorumferugineum) sebagai Sensitizer pada Sel Surya Fotoelektrokimia
}

\author{
Syahrul Khairi \\ Department of Chemical Engineering, Engineering Faculty, \\ Tanjungpura University. \\ e-mail : syahrulkhairi@yahoo.com
}

\begin{abstract}
The Natural dye of Jambal wood (Pelthophorumferugineum) was used as sensitizer in the fabrication of dye sensitizer solar cell (DSSC). The dye was extracted by using solid-liquid extraction method with ethanol as a solvent. UV-Vis spectrophotometer was used to measure the absorbance of dye solution. $\mathrm{TiO}_{2}$ thin-layer was prepared by slip coating method which the pH 5 suspension of $\mathrm{TiO}_{2}$ Degussa on $\mathrm{HCl}$ deposited on a glass substrate Fluorine-doped Tin Oxide (FTO).Dye adsorption was done by the immersion $\mathrm{TiO}_{2}$ thin layer in the dye solution in ethanol for 24 hours after calcination, then used as the working electrode. Counter electrode was prepared by the deposition of gold on the glass substrate.The performance of solar cells sensitized of natural Jambal wood dye was investigated through the measurements of $I_{s c}$ (short circuit currents) and $V_{o c}$ (open circuit voltage on) during irradiation with sun simulated Philips Powertone lamp. The measurement results showed that the solar cell has $I_{s c}$ and $V_{o c}$ by $56 \mathrm{\eta A} / \mathrm{cm}^{2}$ and $394 \mathrm{mV}$ respectively.
\end{abstract}

Keywords-Fotoelektrokimia, Dye Sensitized Solar Cell, zatwarnaalam, Jambal.

\section{Pendahuluan}

Energi matahari adalah bentuk energi elektromagnetik yang dipancarkan ke bumi secara terusmenerus. Energi matahari tidak bersifat polutif dan tak dapat habis. Saat ini energi sinar matahari yang dipancarkan ke planet bumi 15.000 kali lebih besar dibandingkan penggunaan energi global dan 100 kali dibandingkan cadangan batu bara, gas dan minyak bumi. Sel surya merupakan perangkat semikonduktor dengan permukaan luas yang mengubah radiasi matahari menjadi energi listrik secara langsung. Proses yang terjadi dalam sel surya menggunakan efek fotovoltaik. Pada sel surya, listrik dapat dihasilkan dan digunakan secara langsung sehingga tidak terjadi kehilangan daya dan biaya tinggi karena tranmisi kawat. Sel surya sendiri juga bekerja tanpa menimbulkan kebisingan, tidak toksik, tidak menghasilkan gas rumah kaca serta dengan biaya perawatan yang relatif kecil [1] (Halme, 2002).

Awalnya pasar sel surya didominasi oleh sel silikon karena efisiensinya yang tinggi dan stabilitas yang baik, akan tetapi sel silikon ini masih terlalu mahal untuk bersaing secara kompetitif dengan bahan bakar fosil. Biaya untuk membuat sistem fotovoltaik berbasis silikon lengkap dengan efisiensi 12,5\% adalah sebesar 5,5 USD/watt [2] (IEA report, 2002).

Selama kurun waktu satu dekade terakhir ini Dyesensitized nanocrystalline $\mathrm{TiO}_{2}$ solar cell telah dipelajari secara intensif kerena menghasilkan performa yang tinggi dan biaya produksi yang rendah [3] (Gratzel, 2003). Dye Sensitized Solar cell (DSSC) merupakan suatu sel surya fotoelektrokimia yang terdiri dari tiga bagian utama, yaitu working electrode, counter electrode, dan elektrolit [4] (Kartini, 2004). Working elektrode merupakan suatu lapisan tipis semikonduktor yang mempunyai celah pita lebar seperti $\mathrm{TiO}_{2}$ dengan dye sebagai fotosensitiser yang dapat menyerap cahaya pada spektrum sinar tampak.

Penggunaan zat warna alami sebagai sensitiser akan melibatkan langkah pembuatan dan pemurnian zat warna yang semakin mudah dan cepat sehingga bisa menurunkan biaya produksi, mengurangi resiko toksisitas sel surya serta melibatkan proses pembuatan yang ramah lingkungan.

Kayu Jambal merupakan salah satu sumber daya alam yang terdapat di Indonesia dan pemanfaatannya saat ini baru sebatas zat warna batik alami. Melihat potensinya yang masih belum optimal selama ini, maka zat warna alami tersebut dapat digunakan sebagai bahan alternatif untuk pembuatan zat warna pada sel surya.

\section{Dye Sensitized Solar Cell}

Dye Sensitized Solar Cell (DSSC) merupakan sel surya generasi ketiga setelah sel surya berbasis silikon dan semikonduktor polikristalin sebagai dua generasi sebelumnya merupakan sel surya berbasis zat warna dimana lapisan semikonduktror dilapisi dye (zat warna) untuk meningkatkan efesiensi konversi sinar matahari. DSSC terdiri atas working electrode, counter electrode dan elektrolit yang bekerja pada daerah sinar tampak hingga sedikit infra merah. Sinar tampak merupakan gelombang elektromagnetik dengan panjang gelombang 390-770 nm [5] (Skoog, 1985), sedangkan infra merah sedikt lebih panjang, daerah kerja yang jauh lebih lebar dari pada daerah kerja dua generasi sel surya sebelumnya yang bekerja pada daerah Ultra Violet dengan panjang gelombang 10-400 nm. Prinsip kerja dari DSSC sendiri disajikan pada gambar 3, material 
semikonduktor ini ditempatkan pada plat transparan berkonduktifitas membentuk lapisan tipis. Kemudian lapisan monolayer dye ditempatkan pada permukaan lapisan nanokristalin semikonduktor. Fotoeksitasi yang dialami oleh dye menghasilkan elektron tereksitasi dari pita valensi ke pita konduksi dye (1) yang kemudian masuk ke pita konduksi dari logam oksida (2), injeksi elaktron ini melaui hubungan antara titanium dengan gugus karboksil pada zat warna. Proses ini menghasilkan dye yang bermuatan positif dan partikel $\mathrm{TiO}_{2}$ yang bermuatan negatif. Elektron tersebut selanjutnya keluar melalui sirkuit eksternal menuju caunter electrode (3), aliran elektron ini dimanfaatkan sebagai energi listrik. Kekosongan elektron pada pita valensi dye digantikan oleh elektron yang berasal dari elektrolit, elektrolit yang digunakan pada DSSC biasanya adalah pelarut organik yang mengandung sistem redoks, contohnya adalah pasangan iodidatriiodida. Regenerasi sensitiser oleh iodida terjadi dengan proses pendonoran elektron pada pita valensi dari dye yang teroksidasi (5). Iodida diregenerasi kembali dengan reduksi triiodida pada counter electrode, dengan memanfaatkan elektron yang berasal dari eksternal sirkuit (4), proses ini berlangsung terusmenerus sebagai suatu siklus (looping) sehingga dihasilkan arus yang kontinyu [3].

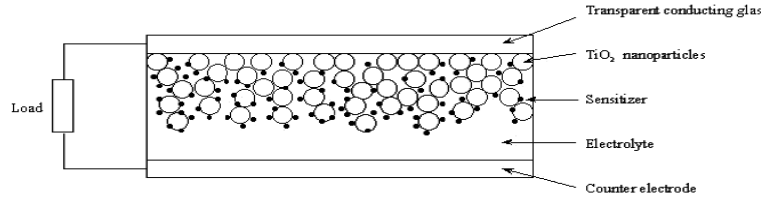

Gambar 1. Skema sandwich sistem DSSC

Sel Surya fotoelektrokimia tersensitasi zat warna sintetis dengan efisiensi lebih dari $10 \%$ menggunakan nano-porous $\mathrm{TiO}_{2}$ semikonduktor oksida dengan katalis platina, telah berhasil dibuat oleh Gratzel [3]. Estimasi biaya sel surya Gratzel dengan mempertimbangkan harga material dan proses pabrikasinya terhadap produknya ialah sebesar $0,48-0,64$ USD/Watt [6] (Smestad, 2003).

Proses pabrikasi sel surya secara efektif dan ekonomis sekarang ini menjadi tantangan tersendiri bagi para peneliti. Beberapa pigmen warna alami mulai digunakan sebagai sensitiser berdasarkan kemampuannya untuk menginjeksikan elektron dari keadaan tereksitasi pada pigmen warna ke pita konduksi dari semikonduktor oksida.

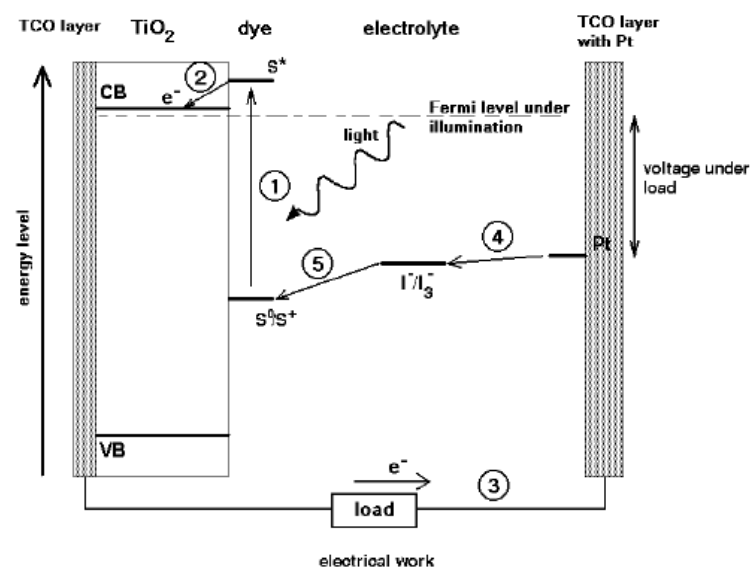

Gambar 2. Prinsip kerja DSSC [3]

Keberhasilan dalam mengkonversi sinar tampak menjadi energi listrik telah didapatkan dengan menggunakan zat warna alami buah jaboticaba (Jaboticaba, Myrtus cauliflora, Mart) dan Java Plum (Jambolao, Eugenia jambolana, Lam) sebagai fotosensitiser dalam DSSC dengan menggunakan katalis elektroda platinum. Arus dan Tegangan (Voltase) sebesar 2,75 mA/cm2 dan $590 \mathrm{mV}$ didapatkan untuk sel surya tersensitasi zat warna dari ekstrak buah jaboticaba dengan Pmax sebesar $778 \mu \mathrm{W} / \mathrm{cm} 2$ dan FF sebesar 0,48. Kemudian dengan kondisi yang sama, didapatkan juga arus dan tegangan sebesar $2,5 \mathrm{~mA} / \mathrm{cm} 2$ dan $439 \mathrm{mV}$ dengan Pmax sebesar $465 \mu \mathrm{W} / \mathrm{cm} 2$ dan FF sebesar 0,42 untuk sel surya tersensitasi zat warna dari ekstrak buah Java Plum [7] (Polo, 2003).

\section{Hasil Eksperimen}

Pada penelitian ini akan dipelajari pengaruh sensitisasi sel surya berbasis semikonduktor $\mathrm{TiO}_{2}$ menggunakan ekstrak alami pewarna batik yaitu kayuJambal (Pelthophorum ferrugineum). Unjuk kerja sel surya oleh perbedaan sensitiser ini dipelajari dengan mengukur tegangan rangkaian terbuka $\left(\mathrm{V}_{\mathrm{oc}}\right)$ dan rapat arus rangkaian hubungan singkat $\left(\mathrm{I}_{\mathrm{sc}}\right)$ dengan penyinaran menggunakan sumber cahaya buatan dari lampu Philips Powertone dalam keadaan gelap atau tanpa cahaya. Harga $V_{o c}$ dan $I_{s c}$ yang dihasilkan dapat memberi gambaran mengenai efisiensi pengubahan energi foton dari cahaya yang mengenai sel surya menjadi sinyal fotolistrik.

Proses ekstraksi zat warna dilakukan denga metode soklet padat cair. Kayu Jambalyang telah dicacah disuspensikan ke dalam pelarut aseton selanjutnya diekstraksi selama 2 jam menghasilkan 20-30 siklus ekstraksi dengan hasil rendemen sebesar 5,5\%.

Untuk mengetahui pita karakter serapan elektronik zat warna Jambal dilakukan pelarutan ektrak zat warna dengan pelarut etanol. Larutan zat warna diukur serapannya pada daerah sinar tampak dengan panjang gelombang 400-800 nm menggunakan spektrofotometer Uv-Vis. Spektra yang dihasilkan merupakan gambaran energi transisi elektronik dari zat warna tersebut oleh pengaruh energi radiasi cahaya. Spektra serapan 
elektronik dari zat warna Jambaldisajikan pada gambar 3 .

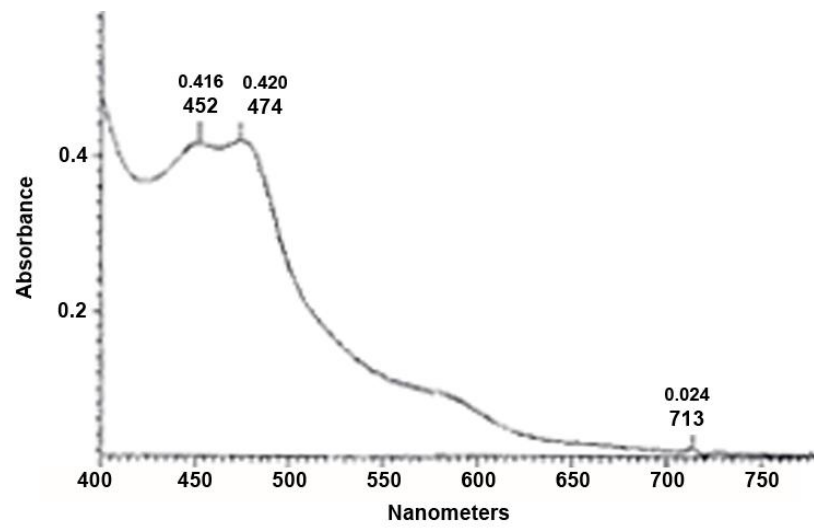

Gambar 3.Spektraabsorbansi UV-

VisekstrakKayuJambaldalampelarutetanol

Padagambar 3 terlihat bahwa zat warna Jambal dalam etanol mempunyai spektra serapan yang melebar pada panjang gelombang 400-750 $\mathrm{nm}$ dengan puncak serapan tertinggi pada $452 \mathrm{~nm}$ dan $474 \mathrm{~nm}$. Hal ini menunjukkan bahwa zat warna Jambal dapat menyerap pada hamper semua panjang gelombang sinar tampak sehingga sesuai bila digunakan sebagai pemanen cahaya atau sensitizer pada sel surya.

Proses deposisi emas dilakukan dengan metode vacum evaporation menggunakan $50 \mathrm{mg}$ emas murni pada 10 pelat kaca berkonduktivitas berukuran $0,5 \times 0,5$ $\mathrm{cm}^{2}$. Pengaturan jarak pelat dengan sumber emas dilakukan untuk mendapatkan lapisan emas yang seragam dan cukup tebal. Semakin jauh dari sumber emas, proses pelapisan akan lebih seragam namun membutuhkan waktu yang lebih lama dan kuantitas emas yang lebih besar untuk mendapatkan ketebalan yang diinginkan. Pada jarak pelapisan $15 \mathrm{~cm}$ dihasilkan lapisan tipis emas berwarna kekuningan yang terlihat seragam. Lapis tipis emas berfungsi sebagai katalis pemisahan muatan pada sel surya pengganti platina. Pelat kaca berlapis emas ini kemudian akan digunakan sebagai counter electrode.

Sebelum dilakukan coating $\mathrm{TiO}_{2}$, pelat kaca dicuci berturut-turut dengan air deterjen, aseton, dan akuades selama 2x20 menit untuk menghilangkan pengotorpengotor yang bersifat polar maupun nonpolar. Proses coating lapisan tipis $\mathrm{TiO}_{2}$ berhasil dilakukan menggunakan larutan $\mathrm{HCl} \mathrm{pH} 5$ sebagai pelarut dan triton-X sebagai perekat. Triton-X yang ditambahkan tidak boleh terlalu banyak karena dapat menimbulkan buih pada suspensi $\mathrm{TiO}_{2}$ dan selanjutnya menyebabkan keretakan pada lapis tipis $\mathrm{TiO}_{2}$. Metode pelapisan yang digunakan adalah metode roll coating menghasilkan lapis tipis $\mathrm{TiO}_{2}$ berwarna putih dengan ukuran $0,5 \times 0,5$ $\mathrm{cm}^{2}$. Pelat kaca berkonduktivitas berlapis $\mathrm{TiO}_{2}$ kemudian dipanaskan sampai suhu $450{ }^{0} \mathrm{C}$ untuk menguapkan pelarut dan mendegradasi triton- $\mathrm{X}$ menjadi $\mathrm{CO}_{2}$ dan $\mathrm{H}_{2} \mathrm{O}$. Pada suhu tersebut terjadi proses sintering $\mathrm{TiO}_{2}$ dan daya lekat $\mathrm{TiO}_{2}$ pada kaca semakin baik. Hasil yang diperoleh berupa pelat berkonduktivitas dengan
$\mathrm{TiO}_{2}$ membentuk lapis tipis yang menutupi secara sempurna pada permukaannya.

Pelat kemudian ditempatkan ke dalam larutan zat warna dengan variasi yang telah ditentukan dengan lama perendaman 24 jam guna memperoleh zat warna yang teradsorpsi sempurna. Pelat dicuci dengan etanol guna menghilangkan larutan zat warna yang tidak terikat langsung pada permukaan $\mathrm{TiO}_{2}$. Hal ini dilakukan karena zat warna yang aktif adalah yang terikat langsung dengan $\mathrm{TiO}_{2}$ membentuk lapisan monolayer. Pengerjaan dilakukan pada ruang gelap guna menghindari degradasi zat warna dalam waktu singkat akibat pengaruh sinar.

Untuk mengetahui adanya sensitisasi zat warna pada lapis tipis $\mathrm{TiO}_{2}$ dilakukan pengukuran serapan elektronik dengan Diffuse Reflectant Uv-Vis (DR-Uv-Vis) pada daerah cahaya tampak. Sensitisasi terjadi bila muncul pergeseran serapan elektronik dari zat warna setelah mengalami adsorpsi pada lapis tipis $\mathrm{TiO}_{2}$ dibandingkan dengan serapan elektronik zat warna dalam kondisi larutan. Pergeseran serapan elektronik terjadi bila terdapat interaksi antara zat warna dengan lapis tipis $\mathrm{TiO}_{2}$ yang memungkinkan adanya transfer elektronik pada daerah antar muka $\mathrm{TiO}_{2}$-zat warna. Serapanelektronik lapis tipis $\mathrm{TiO}_{2}$ danlapis tipis $\mathrm{TiO}_{2}$-zat warnadisajikan pada gambar 4 .

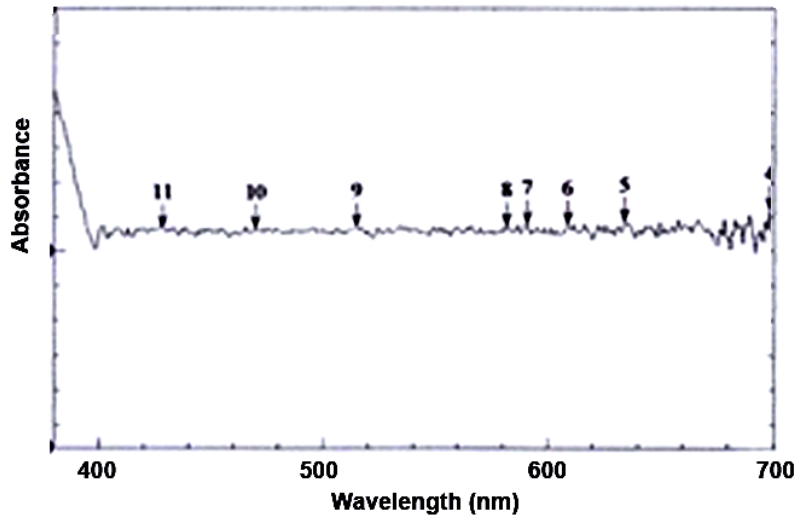

Gambar 4. Spektraabsorpsi lapis tipis $\mathrm{TiO}_{2}$

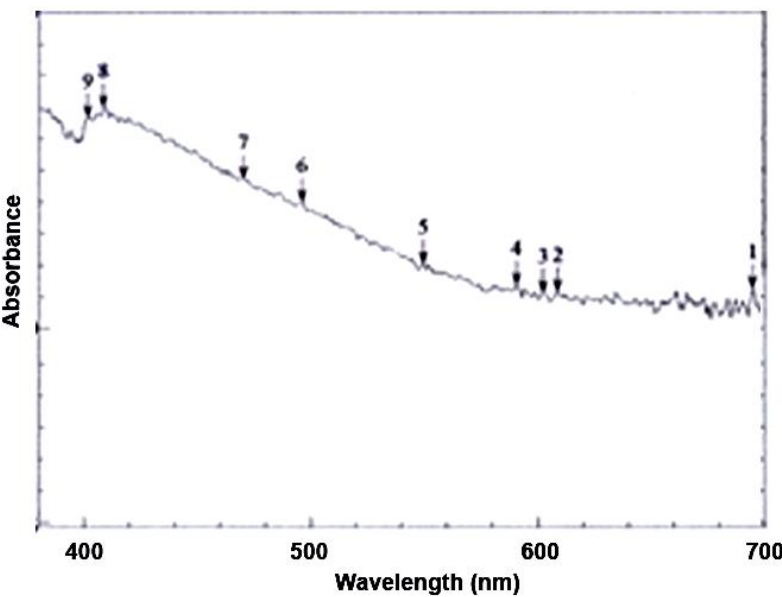

Gambar 5. Spektra absorpsi lapis tipis $\mathrm{TiO}_{2}$-Jambal

Pada gambar diatas terlihat lapis tipis $\mathrm{TiO}_{2}$ tidak mempunyai serapan elektronik pada panjang gelombang cahaya tampak. Adanya adsopsi zat warna Jambal pada 
lapis tipis $\mathrm{TiO}_{2}$ memberikan kontribusi terhadap serapan elektronik pada daerah sinar tampak. Pola serapan yang terbentuk terlihat bersesuaian dengan pola serapan larutan zat warna pada gambar 5. Hal ini menunjukkan bahwa serapan yang terukur adalah serapan dari zat warna yang teradsorpsi pada permukaan $\mathrm{TiO}_{2}$.

Pada spektra absorpsi lapis tipis $\mathrm{TiO}_{2}$-Jambal terlihat adanya pergeseran biru ke arah panjang gelombang yang lebih pendek bila dibandingkan dengan spektra absorpsi larutan zat warna Jambal. Dua puncak karakteristik larutan zat warna Jambal yaitu pada panjang gelombang 452 dan $474 \mathrm{~nm}$ bergeser menjadi 401 dan $408 \mathrm{~nm}$ pada spektra absorpsi lapis tipis $\mathrm{TiO}_{2}$-Jambal. Pergeseran ini menandakan adanya interaksi antara lapis tipis $\mathrm{TiO}_{2}$ dengan sensitiser walaupun jenis interaksi yang terjadi belum diketahui.

Proses konstruksi sandwich sel surya dilakukan sesaat sebelum pengukuran arus dan tegangan dengan maksud untuk menghindari proses degradasi zat warna yang dapat menurunkan aktivitas sel surya pada saat pengukuran kinerja. Kertas saring digunakan sebagai pembatas antar elektroda untuk menghindari kontak antara lapis tipis $\mathrm{TiO}_{2}$ pada working elektroda dengan lapis tipis emas pada counter elektroda agar tidak terjadi transfer elektron yang menyebabkan perendaman (quenching). Selain itu juga untuk menjaga agar larutan elektrolit tidak mudah menguap selama sel bekerja.

Terjadinya sensitisasi zat warna pada lapis tipis $\mathrm{TiO}_{2}$ dapat diketahui dengan membandingkan arus dan tegangan keluar dari sel surya sistem sensitiser dengan sel surya tanpa sensitiser. Besarnya tegangan rangkaian terbuka $\left(\mathrm{V}_{\mathrm{oc}}\right)$ dan rapat arus rangkaian hubungan singkat $\left(\mathrm{I}_{\mathrm{sc}}\right)$ dapat memberikan informasi tentang kinerja masing-masing sel surya. Pengukuran $\mathrm{V}_{\mathrm{oc}}$ dan $\mathrm{I}_{\mathrm{sc}}$ dalam keadaan terang dilakukan dengan intensitas sinar sebesar 2000 lux ( $\pm 20 \mathrm{~cm}$ dibawah lampu). Hasil pengukuran $\mathrm{V}_{\mathrm{oc}}$ dan $\mathrm{I}_{\mathrm{sc}}$ disajikan pada table berikut.

Tabel 1. HasilpengukuranI $\mathrm{I}_{\mathrm{sc}}$ dan $_{\mathrm{oc}}$ dengan variasi sensitiser

\begin{tabular}{ccccc}
\hline \multirow{2}{*}{ Variasisensitiser } & \multicolumn{2}{c}{ Gelap } & \multicolumn{2}{c}{ Terang } \\
\cline { 2 - 5 } & $\mathrm{I}_{\mathrm{sc}} /$ & $\mathrm{V}_{\mathrm{oc}} /$ & $\mathrm{I}_{\mathrm{sc}} /$ & $\mathrm{V}_{\mathrm{oc}} /$ \\
& $\mu \mathrm{A} \cdot \mathrm{cm}^{-2}$ & $\mathrm{mV}$ & $\mu \mathrm{A} \cdot \mathrm{cm}^{-2}$ & $\mathrm{mV}$ \\
\hline Jambal & 44,0 & 383,6 & 56,0 & 394,0 \\
Tanpasensitiser & 4,4 & 10,4 & 6,0 & 15,1 \\
\hline
\end{tabular}

Dari tabel V.2 dapat dilihat bahwa semua sel surya dapat menghasilkan arus listrik walaupun relatif kecil sebagai respon adanya sumber cahaya. Konstruksi pengukuran yang belum sempurna menjadi faktor kecilnya arus terukur. Kontak yang kurang sempurna antara alat pengukur dengan sel surya yang sangat sensitif sehingga voltase saat pengukuran kurang stabil. Selain itu kontruksi sel terbuka menyebabkan penguapan pelarut elektrolit yang cukup cepat. Kemunculan noktah kecil pada sel mengindikasikan bahwa pada bagian tersebut telah kehilangan larutan elektrolitnya. Selain itu kompetisi antara proses injeksi elektron dari keadaan tereksitasike pita konduksi $\mathrm{TiO}_{2}$ dengan proses rekombinasi yang tidak diinginkan juga bisa menyebabkan arus yang kecil.
Dalam keadaan gelap sel surya masih menunjukkan aktivitas berupa keluaran arus dan tegangan. Arus gelap yang terukur jauh lebih kecil daripada arus terang karena tidak adanya proses eksitasi zat warna dalam keadaan tanpa cahaya. Arus gelap ini diakibatkan oleh adanya aktivitas $\mathrm{TiO}_{2}$ yang memberikan elektronnya untuk tereksitasi menggantikan zat warna yang tidak aktif dalam keadaan gelap. Terlihat juga bahwa semakin besar arus gelap, semakin besar pula arus terang yang dihasilkan oleh sel surya.

Interaksi yang terjadi pada sensitiser ekstrak kayu Jambal merupakan interaksi yang membawa serapan ke arah pergeseran biru atau pergeseran serapan ke arah panjang gelombang yang lebih rendah, sehingga serapan yang diharapkan akan mencakup ke arah panjang gelombang yang lebih tinggi tidak terjadi.

Masih dalam serangkaian penelitian ini, efek pencampuran zat warna terhadap kemampuan sensitasi sel surya sebenarnya juga telah dilakukan. Zat warna jambal dicampurkan dengan zat warna kayu Tegeran (Maclura cochinensis). Pencampuran ini bertujuan untuk meningkatkan rentang serapan sinar tampak ke arah merah. Namun hasil yang diperoleh kurang baik, sehingga tidak dijelaskan lebih lanjut dalam tulisan ini.

Padasel surya dengan sensitiser campuran, rapat arus terukur justru lebih kecil daripada sel surya dengan sensitiser tunggal baik dalam keadaan gelap maupun keadaan terang. Hal ini disebabkan karena komponen sensitiser ekstrak kayu Jambal memiliki interaksi yang bersifat membawa daerah serapan ke arah pergeseran biru.Dengan demikian bila dicampurkan dengan zat warna Tegeran, masing-masing sensitiser akan saling mempengaruhi. Adanya pencampuran zat warna juga menghasilkan hambatan yang lebih besar dan sangat rentan terhadap terjadinya peredaman konsentrasi (concentration quenching) [8] (Perera, 2004). Sehingga hipotesis bahwa proses pencampuran zat warna mampu meningkatkan kemampuan absorpsi sinar pada panjang gelombang yang lebih lebar ternyata bergantung juga pada karakteristik masing-masing sensitiser.

Bila dibandingkan dengan sel surya tanpa sensitiser, tampak bahwa adanya sensitiser dari zat warna Jambal mampu meningkatkan rapat arus dan tegangan keluar dari sel surya mencapai sepuluh kali lipat. Hasil ini menunjukkan bahwa ekstrak Jambal merupakan sensitiser yang cukup baik dan efektif dalam mentransfer elektron sepanjang antar muka semikonduktor $\mathrm{TiO}_{2}$ /zat warna. Penggunaan zat warna alam pada akhirnya dapat mewujudkan impian untuk memproduksi sel surya generasi baru dengan biaya yang sangat kecil dan ramah lingkungan.

\section{Kesimpulan}

Proses konstruksi sel surya dengan menggunakan sensitiser zat warna alami yang berasal dari ekstrak kayu Jambal telah berhasil dilakukan melalui pengukuran tegangan $\left(\mathrm{V}_{\mathrm{oc}}\right)$ dan rapat arus $\left(\mathrm{I}_{\mathrm{sc}}\right)$.Adsorpsi zat warna Jambal, menghasilkan pergeseran biru pada pita serapan UV-visibel yang mengindikasikan adanya sensitisasi. Hal ini diperkuat dengan adanya respon fotovoltaik, 
yaitu timbul arus dan beda potensial pada sel surya ketika mendapat penyinaran cahaya tampak.Kinerja sel surya ditunjukkan oleh sel surya dengan sensitiser zat warna kayu Jambal dengan $\mathrm{V}_{\mathrm{oc}}$ dan $\mathrm{I}_{\mathrm{sc}}$ yang dihasilkan sebesar $56 \mu \mathrm{A} . \mathrm{cm}^{-2}$ dan $394 \mathrm{mV}$.

\section{Referensi}

[1] Halme, J., Dye-Sensitized Nanostructured and Organic Photovoltaic Cells: Technical Review and Preliminary Tests, Master Thesis, Helsinki University of Technology, 2002

[2] International Energy Agency, Trends in Photovoltaic Applications in Selected IEA Countries Between 1992 and 2001 in Photovoltaic Power System Program, Report IEA PVPST1-11, 2002.

[3] Gratzel, Michael., Dye-sensitized Solar Cells, Journal of Photochemistry and photobiology C: Photochemistry Reviews,4, 145-153, 2003

[4] Kartini, I., 2004, Synthesis and Characterisation of MesostructuredTitania for Photoelectrochemical Solar cells, PhD Thesis, The University of Queensland, Queensland

[5] Skoog, D, A., Principle of Instrumental Analysis, 3rd edition, Saunders College Publishing, New York, 1985

[6] Smestad, G.P. danGratzel, M., Demonstrating Electron Transfer and Nanotechnology : A Natural Dye-Sensitized Nanocrystalline Energy Converter, J. Chem. Educ., 75, 752-756, 1998

[7] Polo, A.S., Clean and Renewable Energy From DyeSensitized Solar Cells Using Fruit Extracts, RIO 3 - World Climate and Energy Event, 2003

[8] Perera, V.P.S., et al, 2004, A Solar Cell Sensitized With Three Different Dyes, Solar Energy Materials dan Solar Cells, 85, 91-98, 2005

\section{Biography}

Syahrul Khairi, lahir di Pontianak padatanggal 23 Juni 1984. Penulis menempuh pendidikan sarjana dan mendapatkan gelar S.Si pada tahun 2008 di Jurusan Kimia Fakultas Matematika dan Ilmu Pengetahuan Alam Universitas Gadjah Mada, Yogyakarta. Gelar master of engineering (M.Eng) diperoleh setelah menjalani pendidikan di Department of Applied Chemistry and Biotechnology, Faculty of Engineering, Chiba University, Japan pada tahun 2012. Sejak tahun 2014, penulis tercatat sebagai staff pengajar di Program Studi Teknik Kimia, Fakultas Teknik, Universitas Tanjungpura, Pontianak. Hingga saat ini penulis berkonsentrasi pada bidang riset material dan katalis. 